Prepared in cooperation with the Quinault Indtan Nation

\title{
Groundwater Data Collection for the Quinault Indian Nation, Grays Harbor and Jefferson Counties, Washington
}

Data Series 1071
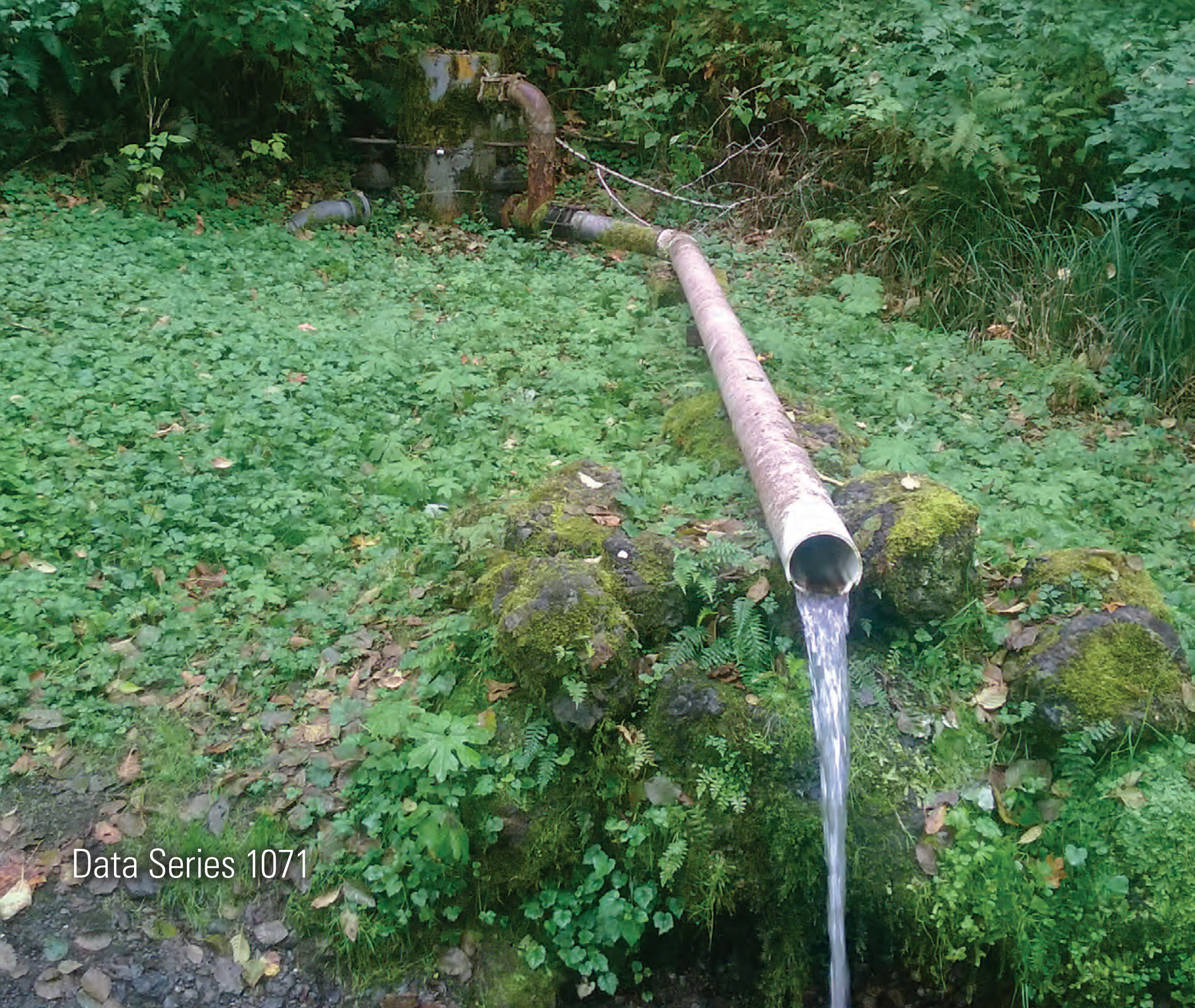

U.S. Department of the Interior

U.S. Geological Survey 
Cover: Unnamed spring near Moclips Highway, Quinault Indian Reservation, Grays Harbor County, Washington. Photograph by Elisabeth Fasser, U.S. Geological Survey, October 3, 2016. 


\section{Groundwater Data Collection for the Quinault Indian Nation, Grays Harbor and Jefferson Counties, Washington}

By Sue C. Kahle, Elisabeth T. Fasser, and Theresa D. Olsen

Prepared in cooperation with the Quinault Indian Nation

Data Series 1071 


\title{
U.S. Department of the Interior \\ RYAN K. ZINKE, Secretary
}

\section{U.S. Geological Survey William H. Werkheiser, Acting Director}

\author{
U.S. Geological Survey, Reston, Virginia: 2017
}

For more information on the USGS - the Federal source for science about the Earth, its natural and living resources, natural hazards, and the environment-visit https://www.usgs.gov or call 1-888-ASK-USGS.

For an overview of USGS information products, including maps, imagery, and publications, visit https://store.usgs.gov.

Any use of trade, firm, or product names is for descriptive purposes only and does not imply endorsement by the U.S. Government.

Although this information product, for the most part, is in the public domain, it also may contain copyrighted materials as noted in the text. Permission to reproduce copyrighted items must be secured from the copyright owner.

Suggested citation:

Kahle, S.C., Fasser, E.T., and Olsen, T.D., 2017, Groundwater data collection for the Quinault Indian Nation, Grays Harbor and Jefferson Counties, Washington: U.S. Geological Survey Data Series 1071, 13 p., https://doi.org/10.3133/ ds1071.

ISSN 2327-638X (online) 


\section{Contents}

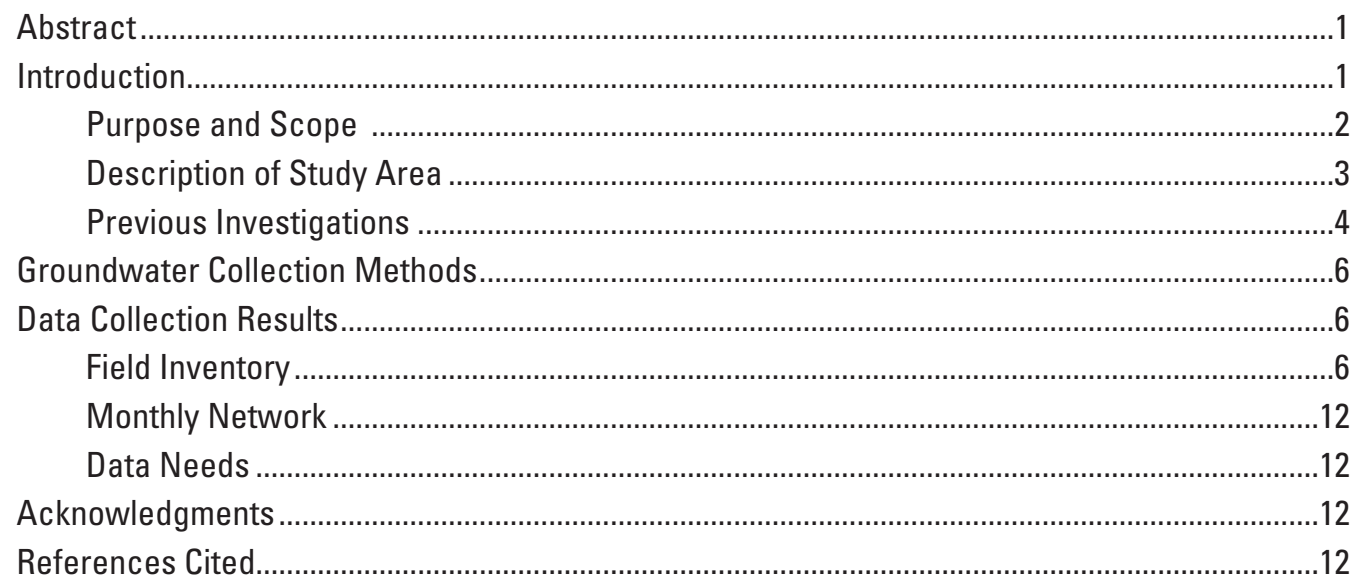

\section{Figures}

1. Map showing location of the Quinault Indian Reservation and U.S. Geological Survey streamgages, Grays Harbor and Jefferson Counties, Washington .......................2

2. Map showing average annual precipitation for the Queets-Quinault watershed, Washington ................................................................................................................

3. Map showing geologic units of the Queets-Quinault watershed, Washington ................5

4. Maps showing location of project wells and springs, including a detailed view of locations near Taholah and surrounding areas, Quinault Indian Reservation, Washington.

\section{Table}

1. Selected physical and hydrologic data for the project wells and springs, Quinault Indian Reservation, Washington

\section{Conversion Factors}

U.S. customary units to International System of Units

\begin{tabular}{|c|c|c|}
\hline Multiply & By & To obtain \\
\hline \multicolumn{3}{|c|}{ Length } \\
\hline inch (in.) & 2.54 & centimeter $(\mathrm{cm})$ \\
\hline inch (in.) & 25.4 & millimeter (mm) \\
\hline foot (ft) & 0.3048 & meter (m) \\
\hline mile (mi) & 1.609 & kilometer (km) \\
\hline \multicolumn{3}{|c|}{ Area } \\
\hline acre & 4,047 & square meter $\left(\mathrm{m}^{2}\right)$ \\
\hline square mile $\left(\mathrm{mi}^{2}\right)$ & 2.590 & square kilometer $\left(\mathrm{km}^{2}\right)$ \\
\hline \multicolumn{3}{|c|}{ Flow rate } \\
\hline cubic foot per second $\left(\mathrm{ft}^{3} / \mathrm{s}\right)$ & 0.02832 & cubic meter per second $\left(\mathrm{m}^{3} / \mathrm{s}\right)$ \\
\hline
\end{tabular}

Temperature in degrees Celsius $\left({ }^{\circ} \mathrm{C}\right)$ may be converted to degrees Fahrenheit $\left({ }^{\circ} \mathrm{F}\right)$ as follows:

$$
{ }^{\circ} \mathrm{F}=\left(1.8 \times{ }^{\circ} \mathrm{C}\right)+32 \text {. }
$$




\section{Datums}

Vertical coordinate information is referenced to the North American Vertical Datum of 1988 (NAVD 88).

Horizontal coordinate information is referenced to the North American Datum of 1983 (NAD 83).

Altitude, as used in this report, refers to distance above the vertical datum.

\section{Well Numbering System}

In Washington, wells are assigned numbers that identify their location in a township, range, section, and 40-acre tract. For example, well number 21N/11W-32E01 indicates that the well is in township 21 north of the Willamette Base Line, and range 11 west of the Willamette Meridian. The numbers immediately following the hyphen indicate the section (32) in the township, and the letter following the section (E) gives the 40 -acre tract of the section. The two-digit sequence number (01) following the letter indicates that the well was the first one inventoried in that 40-acre tract. In the illustrations of this report, wells are identified individually using only the section and 40-acre tract, such as 32E01. The townships and ranges are shown on the map borders.

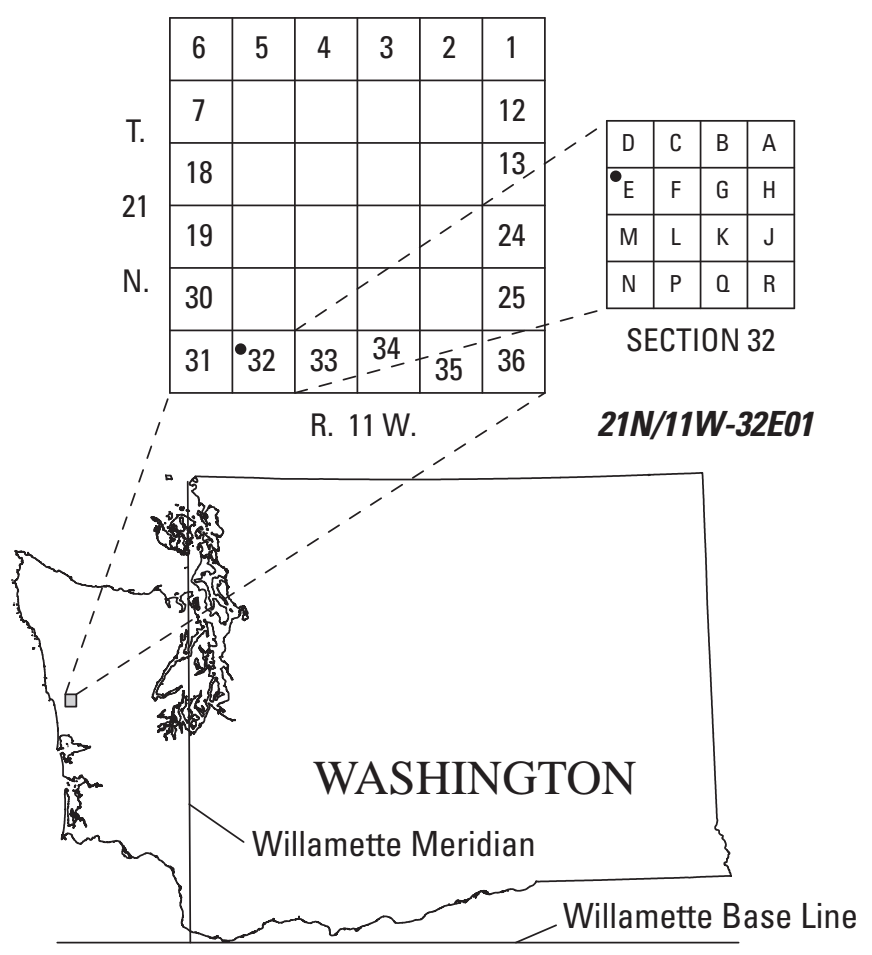




\title{
Groundwater Data Collection for the Quinault Indian Nation, Grays Harbor and Jefferson Counties, Washington
}

\author{
By Sue C. Kahle, Elisabeth T. Fasser, and Theresa D. Olsen
}

\section{Abstract}

Groundwater data were collected on the Quinault Indian Reservation to provide the Quinualt Indian Nation (QIN) with basic knowledge of the existing wells and springs on the reservation, and to establish a water-level network to be monitored by QIN to begin building a long-term groundwater dataset. The $327 \mathrm{mi}^{2}$ Quinault Indian Reservation is located within the heavily forested Queets-Quinault watershed along the west-central coast of Washington and includes the coastal communities of Taholah and Queets, and the inland community of Amanda Park. Groundwater data were collected or compiled for 87 sites - 82 wells and 5 springs. In October 2016, a field inventory was done to locate the sites and acquire site data. Groundwater levels were measured in 15 of the field-inventoried wells and 3 of those wells were observed as flowing (artesian). A monthly groundwater-level monitoring network of 13 wells was established by the U.S. Geological Survey in March 2017, and the network was transferred to QIN in June 2017 for continued measurements.

Several data needs were identified that would provide a more complete understanding of the groundwater system of the Quinault Indian Reservation. The collection of monthly water-level data for multiple years is an important first step in understanding seasonal and long term changes in water levels. Additionally, the collection of baseline groundwater chemistry and quality data across the reservation would help with future efforts to monitor existing and potentially changing groundwater quality conditions. Development of a water budget of the Queets-Quinault Watershed and the reservation within that area would provide water users with a better understanding of this important resource and provide needed information about the competing demands on local water sources.

\section{Introduction}

The Quinault Indian Reservation is located along the west-central coast of Washington State (fig. 1). The reservation includes $23 \mathrm{mi}$ of Pacific Ocean coastline and coastal communities of the Quinault Indian Nation (QIN), including Taholah and Queets. Healthy streams and groundwater supplies are vital to the wellbeing of the QIN. Groundwater is the sole source of fresh drinking water on the reservation, and is supplied from community or single-family wells. Groundwater also helps sustain summer streamflows on the reservation that are essential for salmon. Before this study, groundwater levels were not being monitored routinely.

Climate change can directly affect groundwater throughout the watershed, and is particularly worrisome in vulnerable coastal aquifers (Snover and others, 2013). The Queets-Quinault watershed has already experienced a significant loss of glaciers, and snowmelt is the primary source of streamflow and groundwater recharge throughout most of the watershed. During low snow years such as 2015 with typically higher than normal temperatures, the reduced snowpack results in declines in groundwater recharge and summer/fall streamflow. Any coincidental increases in winter rainfall will be unable to sustain summer and fall streamflows that are already affected by reduced snowpacks in the headwaters of the Queets-Quinault watershed. The effects of climate change may also include changing patterns in precipitation, sea level rise, and saltwater intrusion in coastal aquifers.

Streamflow is monitored by U.S. Geological Survey (USGS) at three sites on the Queets and Quinault Rivers (fig. 1). The QIN is pursuing collection of groundwater data to obtain baseline information that will help with future efforts to monitor trends in groundwater conditions and to augment hydrologic data on the reservation. Monitoring groundwater levels in conjunction with streamflow is necessary to understand groundwater and surface-water interactions, such as sustenance of summer stream flows while maintaining adequate drinking water supplies.

The QIN requested that the USGS conduct an initial groundwater study with the primary goal of making an inventory of the existing water wells on the reservation and to assist in the development of a groundwater-level monitoring network. This work is intended to be followed by subsequent studies that would provide additional information to more fully characterize the groundwater system of the reservation. 


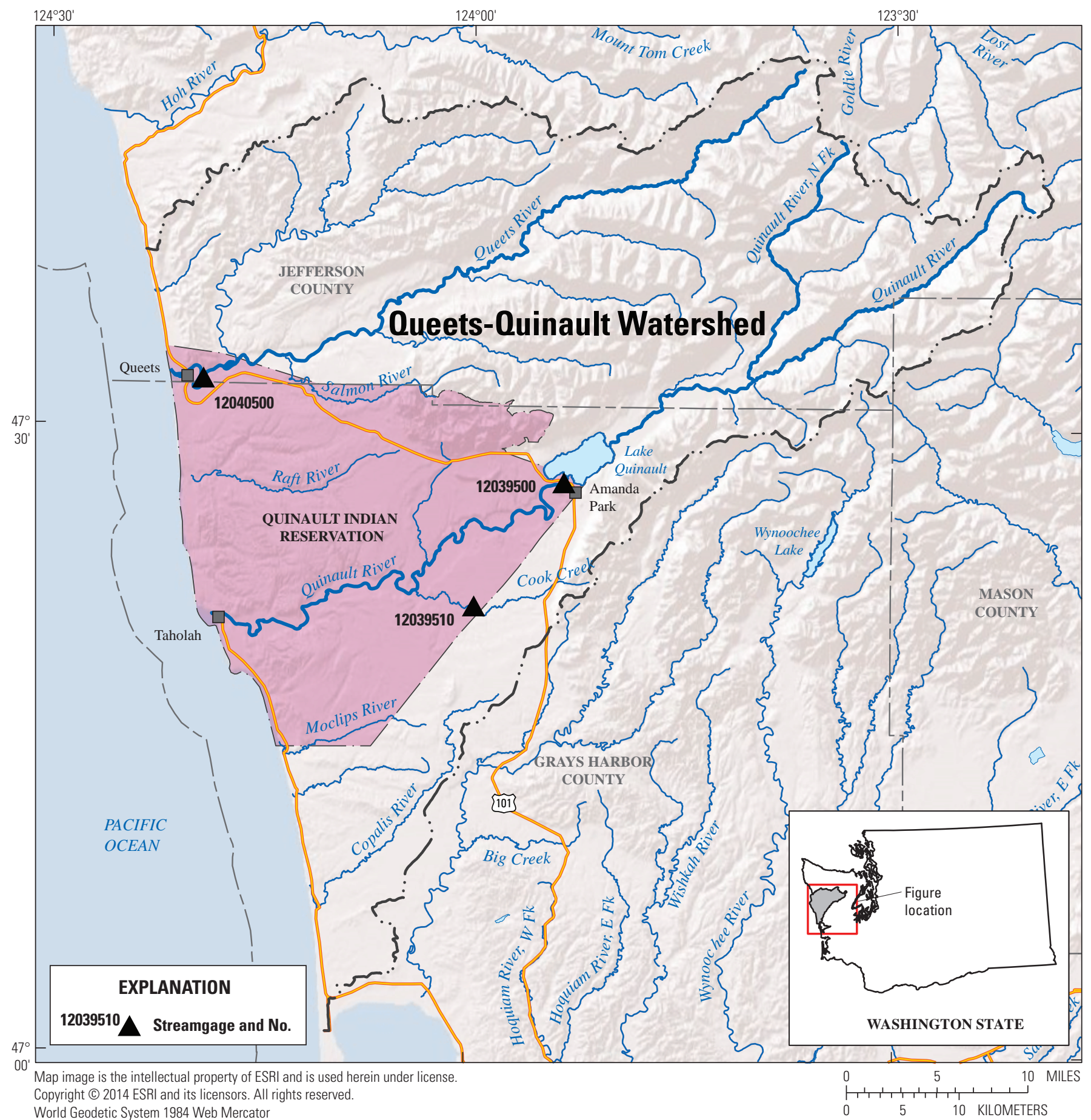

Figure 1. Location of the Quinault Indian Reservation and U.S. Geological Survey streamgages, Grays Harbor and Jefferson Counties, Washington.

\section{Purpose and Scope}

The purpose of this report is to describe the results of the groundwater data collection on the Quinualt Indian Reservation in 2016 and 2017. The topics covered in this report include introductory and background information, and a description of the process and methods of the initial field well inventory, and subsequent monthly groundwater level measurements. Specific products of this report include maps of the well locations, average annual precipitation, and simplified surficial geology, and a table of selected physical and hydrologic data for the project wells. 


\section{Description of Study Area}

The $327 \mathrm{mi}^{2}$ Quinault Indian Reservation is located within the heavily forested Queets-Quinault watershed along the west-central coast of Washington (fig. 1). The easternmost part of the reservation includes Lake Quinault, a glacial-moraine-dammed lake, which separates the upper and lower reaches of the Quinault River (fig. 1). The lower Quinault River flows southwest across the entire reservation from the outlet of Lake Quinault to the Pacific Ocean.

The Raft River flows west across the northern part of the reservation, whereas the Queets, Salmon, and Moclips Rivers cross only parts of the reservation (fig. 1). The terrain is mountainous and altitudes range from more than $2,700 \mathrm{ft}$ in the northeastern most part of the reservation down to sea level at the coast. Average annual precipitation is high and ranges from 66 in. near the coast to more than 150 in. near Lake Quinault (fig. 2).

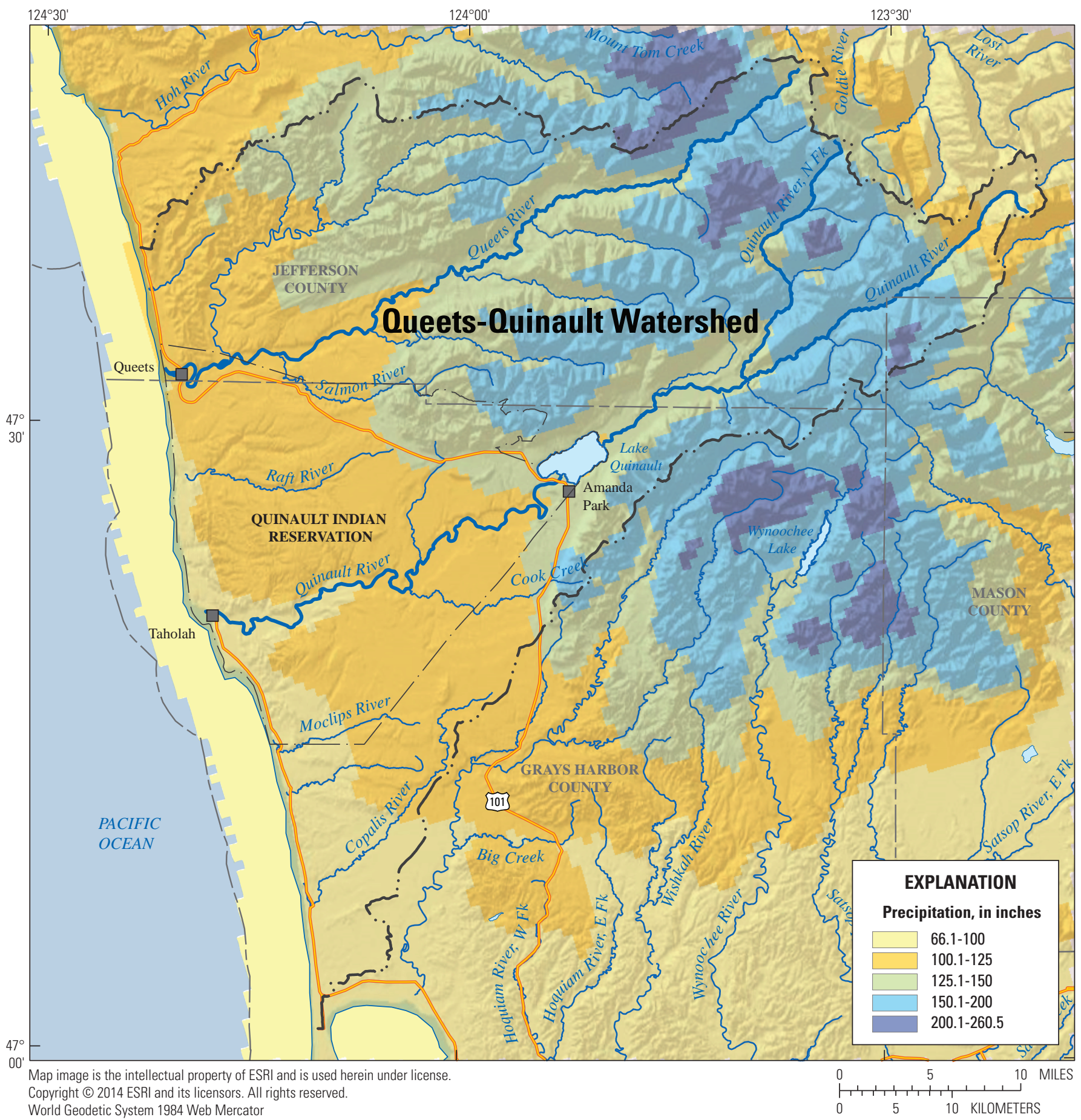

Figure 2. Average annual precipitation for the Queets-Quinault watershed, Washington. 
The geologic units in the study area are mostly Tertiary volcanic (Tv) and marine sedimentary (Tm) rocks overlain by a veneer of much younger Pleistocene alpine glacial drift (Qad) and Quaternary alluvium (Qa). The geologic map of the study area was compiled from the digital geologic map database (1:500,000 scale) for Washington (fig. 3; Schuster, 2005).

\section{Previous Investigations}

Seawater intrusion into coastal aquifers of Washington was first addressed on a regional basis by Walters (1971), for conditions from 1966 through 1968, and later by Dion and Sumioka (1984), for conditions in 1978. Other investigations related to groundwater on or near the Quinault Indian Reservation, are mostly limited to water supply for the town of Taholah. The water-supply studies convey the difficulty in finding freshwater (non-saline) sources of drinking water in the nearshore location of Taholah where shallow wells are often influenced by seawater intrusion and deeper wells reportedly have poor water-quality and (or) low yields (Drost, 1985).

The USGS conducted limited monitoring in 1979 to evaluate saltwater intrusion in Taholah (Drost, 1985), as the community of Taholah, the headquarters of the QIN, was growing and the demands for good quality water for domestic and commercial use were increasing. In 1978 the QIN drilled two wells (21N/13W-1C01 and 1C02; table 1 and fig. 4) to provide additional water sources for growth. However, within hours of pumping, a salty taste in the water was detected and follow up testing indicated high chloride concentrations. The subsequent USGS study involved installing test holes and monitoring water levels and chloride concentrations during a tidal cycle to determine the depth and source of the seawater intrusion.

The identification of reliable sources of good quality water was further investigated by Stay (1988). His work identified three major sources of water with advantages and disadvantages of each, as well as estimates of operation and maintenance of each source. These recommendations included the continued use of springs (21N/13W-01J05S1, -01J06S2, 01J07S3; table 1 and fig. 4), as Taholah's principle water source, creating an infiltration gallery adjacent to the river, and the drilling of additional wells in more optimal locations.
In the early to mid-1990s, Robinson and Noble, Inc., investigated potential new sources of drinking water for Taholah and described their findings in two engineering reports (Robinson and Noble, Inc., 1994, 1995). Through installation and testing of new wells, Robinson and Noble, Inc. described water-bearing and water-quality potential, as well as limitations, at various well sites. In the early 2000s, Robinson and Noble, Inc. contracted and supervised the drilling and testing of several supply wells in the new Moclips River Estates southeast of Taholah (Robinson and Noble, Inc., 2003, 2005).

Effects of climate change including sea-level rise, storm surge, and changes in amount and timing of precipitation have been described in various documents. Snover and others (2013) summarized research since 2007 and prepared a state of knowledge report about the likely effects of climate change on Washington and the Pacific Northwest. The National Research Council (2012) reported on trends and uncertainties associated with sea-level rise, and extrapolated recent data into the future for coastal Washington, Oregon, and California. They also noted that sea level at any given place and time depends on the global sea level and the net contribution of atmospheric, oceanographic, geologic, and anthropogenic processes operating in the area. Huppert and others (2009) describe the effects of climate change on the coasts of Washington and noted stressors including inundation of low-lying areas by high tides as sea level rises; flooding of coasts during major storm events, especially near river mouths; accelerated erosion of coastal bluffs; and saltwater intrusion into coastal freshwater aquifers. Mote and others (2008) provide a summary and calculations of sea-level rise projections for the coastal waters of Washington based on four main forces, (1) thermal expansion of the ocean; (2) melting of land-based ice; (3) local changes in wind, which push coastal waters toward or away from shore; and (4) local movement of the land itself, due primarily to tectonic forces.

Walsh and others (2000) developed a tsunami hazard map of the southern Washington coast based on simulated tsunami inundation from a Cascadia Subduction Zone earthquake. Although the map was prepared to aid local governments in designing evacuation or relocation plans for areas at risk from potentially damaging tsunamis, it is also helpful to identify areas where existing water wells might be inundated with sea water during such an event. 


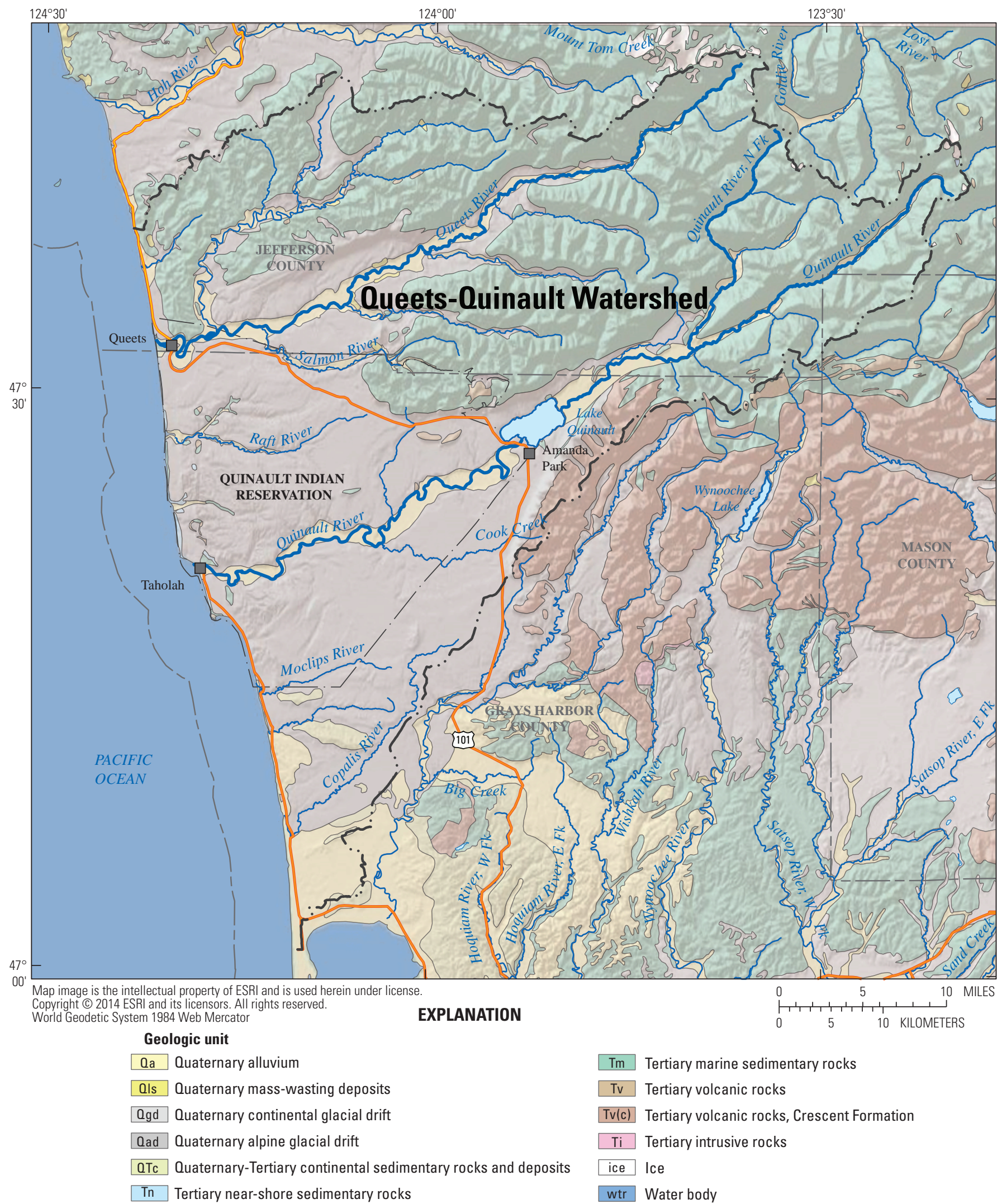

Figure 3. Geologic units of the Queets-Quinault watershed, Washington. 


\section{Groundwater Collection Methods}

Available groundwater records were compiled and evaluated to plan and conduct field inventory of wells and springs on the Quinault Indian Reservation. The records included drillers' logs, historical groundwater levels, and geologic maps; and available groundwater level and spring records. During the field inventory, wells and springs were located, and the depth to water in wells was measured depending on accessibility. Based on available wells with measurable water levels, a monthly groundwater-monitoring network was established and QIN personnel were trained to monitor the groundwater network.

Available well and spring records were compiled and sites were located in the field during autumn 2016. Well selection was generally based on the availability of a drillers' report for the well (obtained from the Washington Department of Ecology or other sources), the availability of lithologic and construction information on the drillers' report, and permission from the owner or tenant to visit the site. At the time of inventory, the groundwater level was measured if feasible and a field form was completed noting the location, well construction information, and water level at each site. The depth to water in wells was measured using tape-down procedures. The documentation of technical procedures for groundwater data-collection activities is contained in the USGS Techniques and Method report 1-A1 "Groundwater Technical Procedures of the U.S. Geological Survey" (Cunningham and Schalk, 2011). This report provides detailed, illustrated instructions for the implementation of common field methods for collecting groundwater data. Global Positioning System (GPS) hand-held units were used during the inventory to determine the latitude and longitude of each site with a horizontal accuracy of one-tenth of a second (about $10 \mathrm{ft}$ ). Land-surface altitude for each well and spring was obtained from a digital elevation model with 10-m square cells using the latitude and longitude for each site. All water-level measurements were measured by USGS personnel according to standardized techniques of the USGS (Cunningham and Schalk, 2011; Kozar and Kahle, 2013). Information for all sites (wells and springs) was entered in the USGS National Water Information System database (https://waterdata.usgs. gov/).

Water levels in wells were measured with steel tapes or electronic tapes. If the tape required a correction based on an accompanying calibration table, the correction was noted on the field sheet. All measurements were confirmed-taken twice, with at least 3-5 minutes between measurements. The confirmation measurement needed to be within $0.02 \mathrm{ft}$ to be considered a static water-level measurement. If the initial measurements were not in agreement, additional measurements were made until the water level status was determined (for example, recovering or pumping).

The location of wells and springs as determined by GPS were documented with latitude and longitude values reported in ddmmss.ss (degrees, minutes, seconds). The latitude and longitude were read and recorded on the field sheet after water-level measurements were completed, to give sufficient time for GPS readings to stabilize. Values between the GPS unit and the field sheet were double-checked before departing the site. A sketch map showing location of the well or spring was made on the field sheet. This map is intended for future visits and can include measured distances (vehicle odometer) from road intersections and estimated or paced distances from identifiable site features (such as, buildings, driveways, creeks, or fences).

All hydrologic data collected during this study was compiled and entered into the USGS National Water Information System (NWIS) database (https://waterdata.usgs. gov/). Geospatial data was compiled and entered in a newly created Geographic Information Systems (GIS) database for the project.

\section{Data Collection Results}

The primary components of this investigation-a field inventory of wells and springs, establishing a monthly water-level network and the training of QIN personnel to maintain the network, and the identification of data gaps that would need to be addressed to fully characterize the groundwater system are described below.

\section{Field Inventory}

The project dataset includes 87 sites - 82 wells and 5 springs. In October 2016, a field inventory was done to field locate the sites and to acquire site data including measuring depth to water in as many wells as possible. The location and associated information for wells on the reservation were obtained from past reports, the Washington Department of Ecology, Washington Department of Health, Indian Health Services, and personnel from the QIN. The intent of the field inventory was to collect data from wells and springs evenly distributed throughout the reservation. This was not possible in all areas because of lack of development on much of the reservation, or lack of permission to access some sites. Locations of the inventoried wells and springs are shown on figure $4 \mathrm{~A}$ and $\mathrm{B}$, and selected physical and hydrologic data for the wells are provided in table 1 . Table 1 includes historical water levels as well as those collected for this study.

Most of the project sites are concentrated in or near the town of Taholah, along the coast south of Taholah, in Amanda Park, and in Queets (fig. 4B). The sites concentrated in Taholah include 25 test holes or monitoring wells (table 1) utilized during water supply and seawater intrusion studies done in the late 1970s to mid-1980s (Drost, 1985; Stay, 1988). Most of these sites have been destroyed and only one monitoring well (21N/13W-12A01 TW-07; fig. 4B and table 1) was located during the field inventory. 


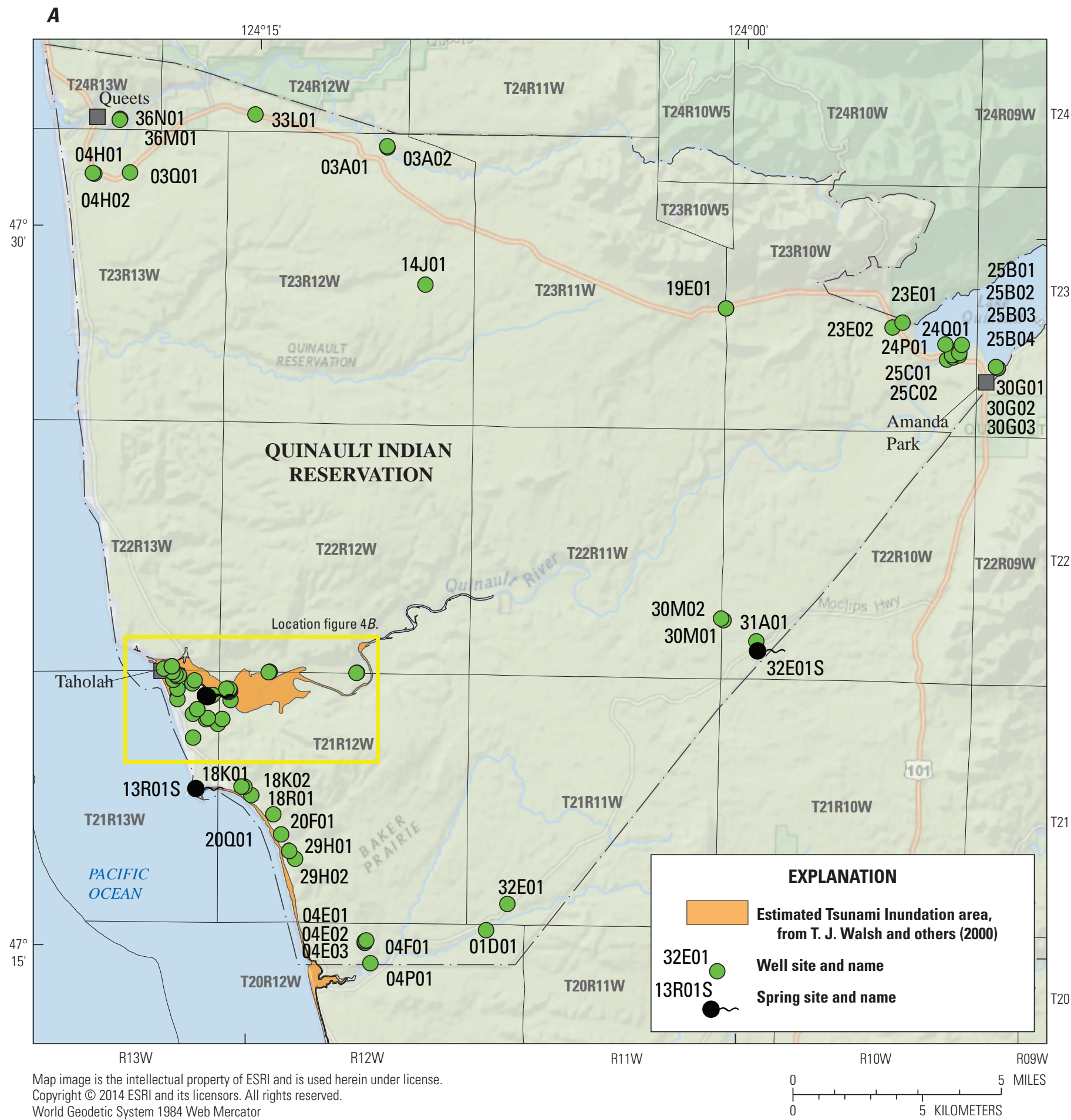

Figure 4. (A) Location of project wells and springs, including $(B)$ a detailed view of locations near Taholah and surrounding areas, Quinault Indian Reservation, Washington. For explanation of well numbers, see section, "Well Numbering System." 


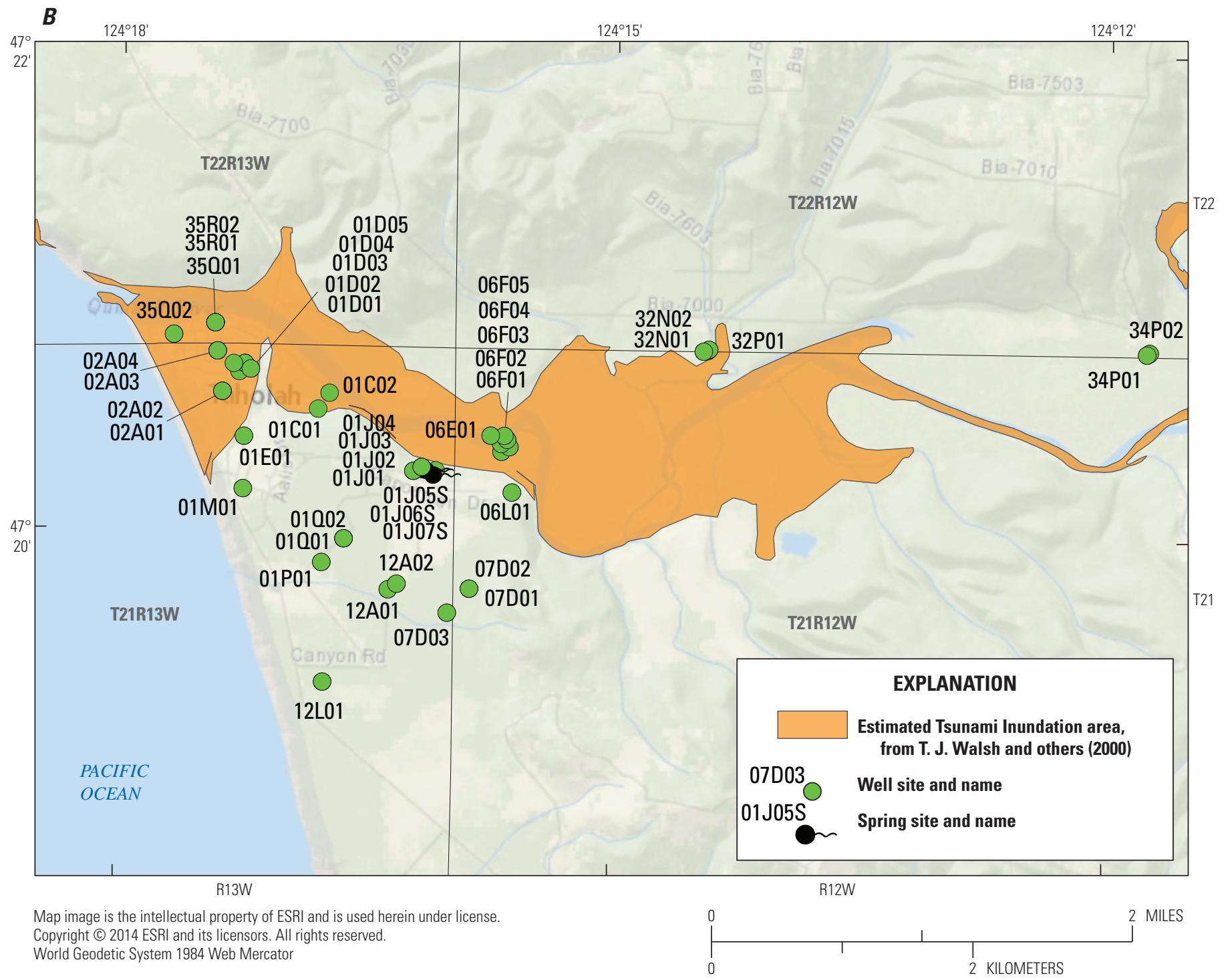

Figure 4.-Continued 


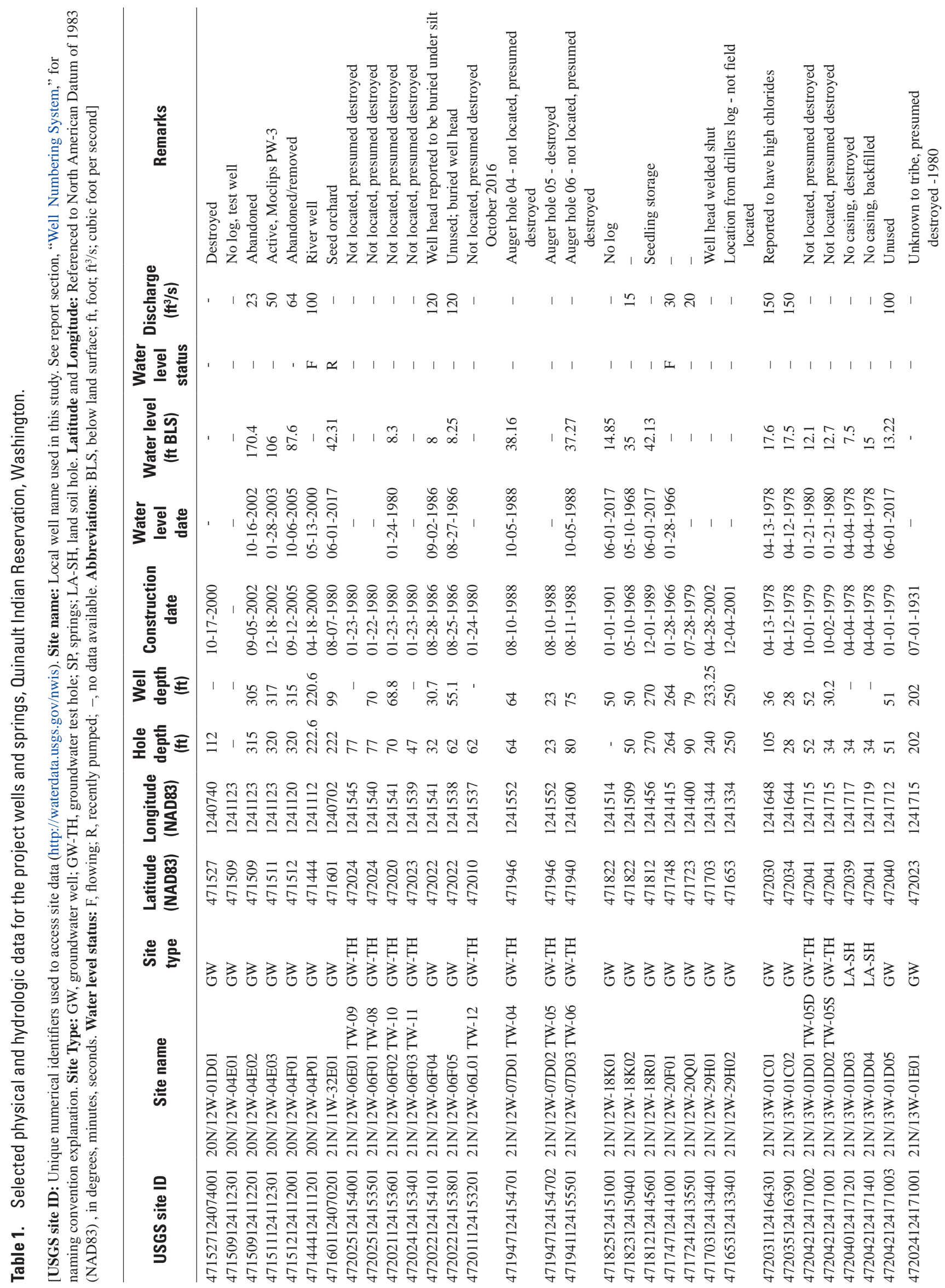




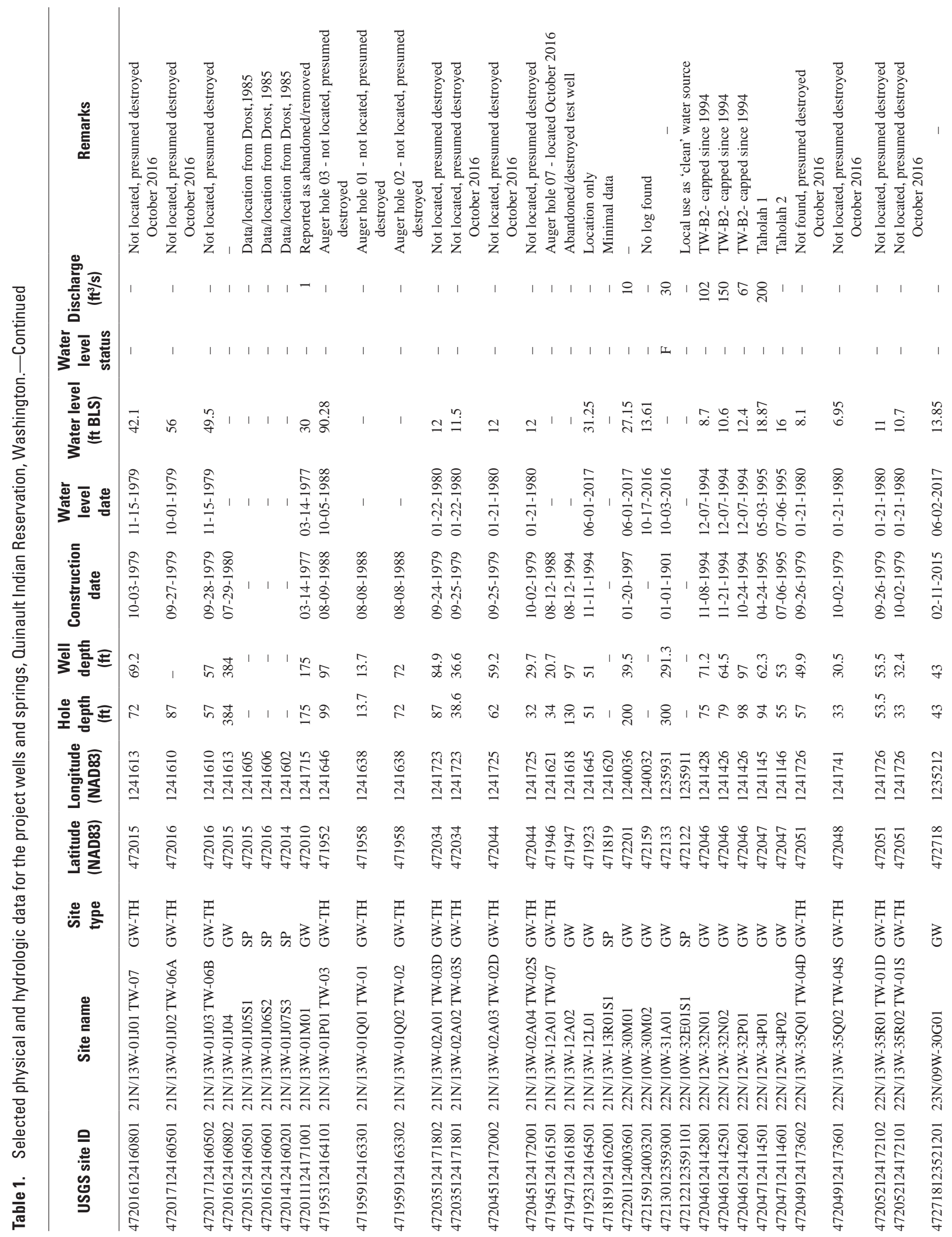




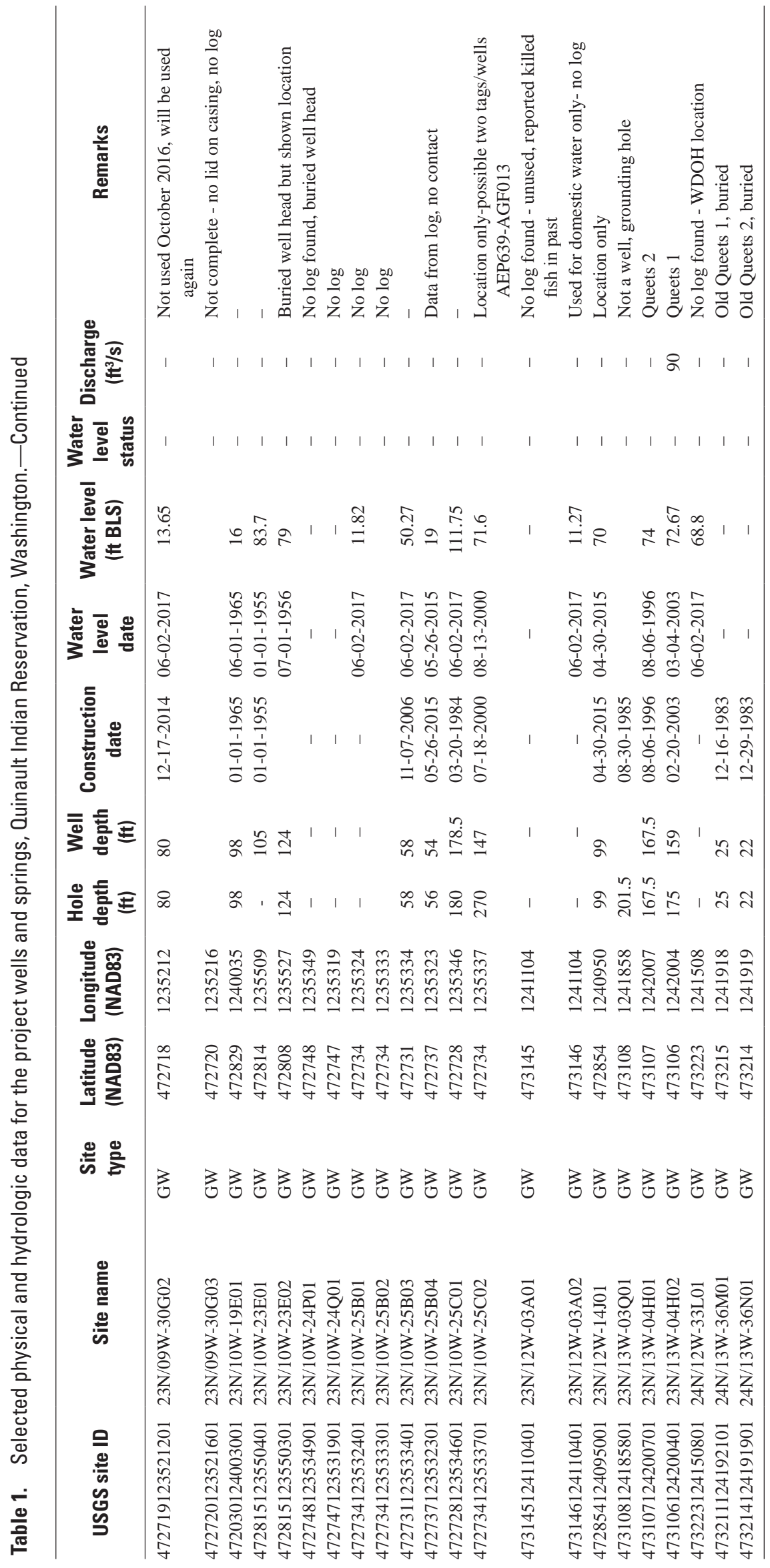


Depth to water (water level) was measured in 15 of the field-inventoried wells (table 1) using an electric tape or graduated steel tape, using methods previously described. Three wells were observed as flowing (artesian) (table 1), meaning that the water level was above the land surface altitude at the well. At many sites, water levels were not measured because of access issues including buried well heads, welded well caps, or a lack of permission to measure.

\section{Monthly Network}

After completion of the well and spring inventory, 13 of the field-located wells were selected for use in a monthly groundwater-level monitoring network. Starting in March of 2017, the USGS established a monthly network, and USGS personnel measured the wells through June 2017 (table 1) before training QIN personnel and transferring the network to the QIN for continued measurements. The USGS provided guidance to the QIN on procuring necessary equipment and provided field sheets to allow for adequate long-term data collection to be comparable to past records. In late June 2017, the USGS led a 2-day hands-on training of the water level protocol and the monthly network. This training included introductions to well owners, well locations, use of new equipment, and data requirements to have a complete long-term record of water levels. The USGS followed up with QIN in August 2017 on data collection procedures and maintenance of data to ensure that records are complete.

\section{Data Needs}

During the course of this study, several data needs were identified that, if filled, would provide a more complete understanding of the groundwater system of the Quinault Indian Reservation, along the west-central coast of Washington State. The collection of monthly water-level data is an important first step in understanding changes in seasonal and long-term water levels. Additionally, the collection of baseline water chemistry and quality across the reservation would help with future efforts to monitor existing and potentially changing groundwater quality conditions. An immediate benefit would include identification of possible anthropogenic contaminants such as nutrients and naturally occurring contaminants such as chloride, sulphur, and arsenic. Freshwater sources of the reservation are susceptible to deterioration from a variety of factors including those related to climate change such as changes in amount and timing of groundwater recharge and sea level rise and storm surge. Nearshore groundwater sources are also susceptible to contamination from catastrophic inundation from tsunamis. A baseline understanding of existing groundwater conditions (water levels and water quality), possible threats to those conditions, and perhaps prediction of effects through computer modeling may assist the Quinault Indian Nation in managing these critical resources through time.
The development of a water budget of the Queets-Quinault watershed and the Quinault Indian Reservation would provide water users a better understanding of this resource and provide necessary information about the competing demands on local water sources. An important component of a water budget is the measurement of stream discharge throughout the watershed during low-flow conditions which would help identify gaining and losing stream reaches, and further the understanding of groundwater and surface-water interactions in the watershed.

\section{Acknowledgments}

The USGS gratefully acknowledges the landowners on the Quinault Indian Reservation who allowed access to their land and wells and shared their knowledge about the water resources of the area. Electronic copies of hard-to-find documents regarding the water resources of the Taholah area were graciously provided directly from authors, Robinson and Noble, Inc., and Carl Stay.

\section{References Cited}

Cunningham, W.L., and Schalk, C.W., comps., 2011, Groundwater technical procedures of the U.S. Geological Survey: U.S. Geological Survey Techniques and Methods 1-A1, 151 p. (available only online at http://pubs. usgs.gov/tm/1a1/).

Dion, N.P., and Sumioka, S.S., 1984, Seawater intrusion into coastal aquifers in Washington, 1978: U.S. Geological Survey Water-Supply Bulletin 56, 13 p.

Drost, B.W., 1985, Appraisal of ground-water conditions and potential for seawater intrusion at Taholah, Quinault Indian Reservation, Washington: U.S. Geological Survey Water-Resources Investigations Report 84-4361, 26 p.

Huppert, D.D., Moore, A., and Dyson, K., 2009, Chapter 8Coasts, in Climate Impacts Group, The Washington climate change impacts assessment-Evaluating Washington's future in a changing climate: Seattle, Washington, University of Washington, p. 285-309, accessed January 2017, at https://cig.uw.edu/publications/impacts-ofclimate-change-on-the-coasts-of-washington-state/.

Kozar, M.D., and Kahle, S.C., 2013, Quality-assurance plan for groundwater activities, U.S. Geological Survey, Washington Water Science Center: U.S. Geological Survey Open-File Report 2013-1151, 88 p., http://pubs.usgs.gov/ ofr/2013/1151/. 
Mote, P.W., Petersen, A., Reeder, S., Shipman, H., and Whitely Binder, L.C., 2008, Sea level rise in the coastal waters of Washington State: Seattle, Washington, University of Washington and the Washington Department of Ecology, Climate Impacts Group, 11 p.

National Research Council, 2012, Sea-level rise for the coasts of California, Oregon, and Washington-Past, present, and future: Washington D.C., The National Academies Press, National Research Council, 202 p., https://doi. org/10.17226/13389.

Robinson and Noble, Inc., 1994, Taholah alternate water source facilities plan, Quinault Indian Reservation, Washington-Phase 1 report: Tacoma, Washington, Robinson and Noble, Inc., 50 p.

Robinson and Noble, Inc., 1995, Taholah alternate water source facilities plan, Quinault Indian Reservation, Washington-Phase 2 report: Tacoma, Washington, Robinson and Noble, Inc., 77 p.

Robinson and Noble, Inc., 2003, Moclips River Estates construction and testing of production wells 1 and 2: Tacoma, Washington, Robinson and Noble, Inc., 70 p.

Robinson and Noble, Inc., 2005, Construction and testing of production well 4 with wellfield analysis, Qui-Nai-Elt Village: Tacoma, Washington, Robinson and Noble, Inc., $102 \mathrm{p}$.
Schuster, J.E., 2005, Geologic map of Washington state: Washington Division of Geology and Earth Resources Geologic Map GM-53, 1 sheet, scale 1:500,000, with 44 p. text, http://www.dnr.wa.gov/geology/pubs/pubs_ol.htm.

Snover, A.K., Mauger, G.S., Whitely Binder, L.C., Krosby, M., and Tohver, I., 2013, Climate change impacts and adaptation in Washington State: Seattle, Washington, University of Washington, Climate Impacts Group,Technical Summaries for Decision Makers, State of Knowledge Report prepared for the Washington State Department of Ecology, 130 p.

Stay, C.B., 1988, Taholah water investigation at the Quinault Indian Reservation, Western Olympic Peninsula, Washington: Provo, Utah, Brigham Young University College of Engineering and Technology, $52 \mathrm{p}$.

Walsh, T.J., Caruthers, C.G., Heinitz, A.C., Myers, E.P., III, Baptista, A.M., Erdakos, G.B., and Kamphaus, R.A., 2000, Tsunami hazard map of the southern Washington coastModeled tsunami inundation from a Cascadia subduction zone earthquake: Washington Division of Geology and Earth Resources Geologic Map GM-49, 1 sheet, scale 1:100,000, with 12 p. text, http://www.dnr.wa.gov/ Publications/ger_gm49_tsunami_hazard_southern_coast. zip.

Walters, K.L., 1971, Reconnaissance of sea-water intrusion along coastal Washington, 1966-68: U.S. Geological Survey Water-Supply Bulletin 32, 51 p. 

Publishing support provided by the U.S. Geological Survey

Science Publishing Network, Tacoma Publishing Service Center

For more information concerning the research in this report, contact the Director, Washington Water Science Center

U.S. Geological Survey

934 Broadway, Suite 300

Tacoma, Washington 98402

https://wa.water.usgs.gov 
車

蛋

올.

总 